\title{
Long term renal outcome of childhood haemolytic uraemic syndrome
}

\author{
Margaret M Fitzpatrick, Vanita Shah, Richard S Trompeter, Michael J Dillon, T Martin Barratt
}

\section{Abstract}

Objective-To evaluate the long term outcome of renal function in infants and children after diarrhoea associated haemolytic uraemic syndrome.

Setting-The Hospital for Sick Children, Great Ormond Street, and the Royal Free Hospital, London.

Subjects -103 children with the syndrome who presented between 1966 and 1985; 88 attended for follow up investigations (40 male, 48 female) with a mean age 11.6 (range 5.2-22.6) years and a mean duration of follow up of $8 \cdot 5$ (range $5 \cdot 1-21 \cdot 3$ ) years.

Main outcome measures-Blood pressure, ratio of early morning urine albumin to creatinine concentration, glomerular filtration rate, and plasma renin activity.

Results - The mean (SD) systolic blood pressure standard deviation score was $0.38(0.67)$ and diastolic blood pressure SD score was $0 \cdot 10(0 \cdot 76)$. The geometric mean ratio of overnight urine albumin to creatinine concentration was $1 \cdot 27$ (range 0.03-48.2), significantly higher than the value observed in 77 normal children $(0.32(0.05-1.95), p<0.0001)$. Glomerular filtration rate estimated from the plasma clearance of chromium-51 EDTA was 95.1 $(22.7) \mathrm{ml} / \mathrm{min} / 1.73 \mathrm{~m}^{2}$ surface area, and 16 children had a rate of $\leqslant 80 \mathrm{ml} / \mathrm{min} / 1.73 \mathrm{~m}^{2}$. Significant negative correlations were found between glomerular filtration rate and urinary albumin to creatinine ratio $(r=-0.41, p<0.0001)$ and glomerular filtration rate and systolic blood pressure SD score $(\mathrm{r}=-\mathbf{0} \cdot 48, \mathrm{p}<0.0001)$. A significant positive correlation was found between urinary albumin to creatinine ratio and systolic blood pressure SD score $(\mathrm{r}=0.25, \mathrm{p}=0.02)$

Conclusions - After an acute episode of diarrhoea associated haemolytic uraemic syndrome $31 \%$ $(27 / 88)$ of children had an increased albumin excretion, $18 \%(16 / 88)$ had a reduced glomerular filtration rate and $10 \%(9 / 88)$ had both, in association with a higher systolic blood pressure, indicating considerable residual nephropathy in this group.

Child Health, London WC1N 1EH

Margaret M Fitzpatrick, MRCP, lecturer in paediatric nephrology

Vanita Shah, FIMLs, chief medical laboratory scientific officer

Richard S Trompeter, FRCP, consultant paediatric nephrologist

Michael J Dillon, FRCP, consultant paediatric nephrologist

T Martin Barratt, FRCP, consultant paediatric

nephrologist

Correspondence to:

Dr Fitzpatrick.

BMF 1991;303:489-92

\section{Introduction}

The haemolytic uraemic syndromes are a heterogeneous group of disorders characterised by haemolytic anaemia, thrombocytopenia, and renal failure. Two main subgroups are now recognised: the first is associated with a diarrhoeal prodrome and is a major cause of acute renal failure in children in Britain, whereas the second, which is rare in childhood, has no antecedent diarrhoea. ${ }^{2}$ During the past decade, with the discovery that Escherichia coli producing verocytotoxin are an important cause of diarrhoea associated haemolytic uraemic syndrome, ${ }^{3}$ there have been considerable advances in understanding the aetiology and pathogenesis of this disorder. The long term outcome for renal function in those patients who survive the acute phase of the illness is, however, incompletely documented. This paper reviews the long term outcome of renal function in 88 infants and children evaluated five to 21 years after the acute phase of the syndrome.

\section{Methods}

From 1966 to 1985 a total of 120 infants and children with haemolytic uraemic syndrome were admitted to the Hospital for Sick Children, Great Ormond Street, and the Royal Free Hospital, London. One hundred and three had a "typical" enteropathic illness with a diarrhoeal prodrome and 17 an "atypical" presentation without diarrhoea. A follow up study was undertaken of the children whose illness had the diarrhoeal prodrome. Ethical approval for this study was obtained from the ethics committee of the Hospital for Sick Children, Great Ormond Street.

Of the original 103 children with diarrhoea associated haemolytic uraemic syndrome (table I), 15 were not included in the study. Eight had died, five during the acute phase of the illness, and three had progressed to end stage renal failure after their initial presentation and died after dialysis or transplantation (table II).

TABLE I-Children with diarrhoea associated haemolytic uraemic syndrome included and not included in study. None presented in 1967 and 1970

\begin{tabular}{|c|c|c|c|c|}
\hline Year & $\begin{array}{c}\text { No } \\
\text { presenting }\end{array}$ & $\begin{array}{c}\text { No } \\
\text { followed up }\end{array}$ & $\begin{array}{c}\text { No } \\
\text { died }\end{array}$ & $\begin{array}{l}\text { No not } \\
\text { available }\end{array}$ \\
\hline 1966 & 2 & & 2 & \\
\hline 1968 & 1 & 1 & & \\
\hline 1969 & 1 & & 1 & \\
\hline 1971 & 6 & 5 & $i$ & \\
\hline 1972 & 3 & 3 & & \\
\hline 1973 & 5 & 4 & & 1 \\
\hline 1974 & 4 & 2 & & 2 \\
\hline 1975 & 4 & 4 & & \\
\hline 1976 & 3 & 2 & & 1 \\
\hline 1977 & 3 & 1 & 2 & 1 \\
\hline 1979 & 1 & 1 & & \\
\hline 1980 & 9 & 8 & 1 & \\
\hline 1981 & 5 & 4 & & 1 \\
\hline 1982 & 8 & 8 & & \\
\hline 1983 & 6 & 6 & & \\
\hline 1984 & 22 & 21 & & 1 \\
\hline 1985 & 19 & 18 & 1 & \\
\hline
\end{tabular}

Seven other children were not available for study because they lived abroad (two), were unwilling to cooperate in the study (two), or could not be located (three). Of the 88 patients who attended for follow up investigations, 40 were male and 48 female; they had a mean age of 11.6 (range $5 \cdot 3-22 \cdot 6$ ) years. The mean duration of follow up was $8 \cdot 5(5 \cdot 1-21 \cdot 3)$ years.

The patients were reviewed as day cases, bringing with them an early morning urine sample in which the ratio of urinary albumin to creatinine concentration was measured. Blood pressure was measured using a random zero sphygmomanometer. ${ }^{+}$Blood samples were taken for estimation of glomerular filtration rate and plasma renin activity.

Blood pressure was measured in the right arm with the patient seated, by using a random zero 
TABLE II -Characteristics of eight patients with diarrhoe'a associated haemolytic uraemic syndrome who died

\begin{tabular}{|c|c|c|c|c|c|c|}
\hline \multirow[b]{2}{*}{ Sex } & \multirow[b]{2}{*}{$\begin{array}{c}\text { Year of } \\
\text { presentation }\end{array}$} & \multirow[b]{2}{*}{ Age (years) } & \multirow[b]{2}{*}{$\begin{array}{l}\text { White blood } \\
\text { cell count } \\
\left(\times 10^{\prime \prime} / 1\right)\end{array}$} & \multirow[b]{2}{*}{$\begin{array}{l}\text { Duration of } \\
\text { dialysis } \\
\text { (days) }\end{array}$} & \multicolumn{2}{|c|}{ Death } \\
\hline & & & & & $\begin{array}{l}\text { Time after } \\
\text { presentation } \\
\text { (months) }\end{array}$ & Cause \\
\hline$M$ & 1966 & $0 \cdot 6$ & $27 \cdot 6$ & 14 & $0 \cdot 5$ & Cerebral \\
\hline $\mathrm{F}$ & 1966 & $1 \cdot 1$ & $32 \cdot 9$ & 48 & 1.6 & Septicaemia \\
\hline $\mathrm{F}$ & 1969 & $0 \cdot 2$ & $26 \cdot 7$ & & $0 \cdot 2$ & Cerebral \\
\hline $\mathrm{F}$ & 1971 & 0.5 & $14 \cdot 8$ & 56 & 6 & Cerebral \\
\hline $\mathrm{F}$ & 1978 & 11 & $22 \cdot 9$ & 28 & $5 \cdot 5$ & Cardiac \\
\hline$M$ & 1978 & 1 & $41 \cdot 3$ & 28 & 84 & Septicaemia \\
\hline$M$ & 1980 & 2 & $37 \cdot 4$ & 6 & $0 \cdot 2$ & Colitis \\
\hline $\mathrm{F}$ & 1985 & 3 & $22 \cdot 9$ & 9 & $0 \cdot 3$ & Cerebral \\
\hline
\end{tabular}

TABLE III-Standard deviation scores for systolic blood pressure in 88 patients with diarrhoea associated haemolytic uraemic associated handrome
synt

\begin{tabular}{lc}
\hline $\begin{array}{l}\text { Standard } \\
\text { deviation } \\
\text { score }\end{array}$ & $\begin{array}{c}\text { No of } \\
\text { patients }\end{array}$ \\
\hline$-1 \cdot 0-$ & 7 \\
$-0 \cdot 5-$ & 22 \\
$0-$ & 21 \\
$0 \cdot 5-$ & 19 \\
$1 \cdot 0-$ & 13 \\
$1 \cdot 5-2 \cdot 0$ & 6 \\
\hline
\end{tabular}

sphygmomanometer, the arm being supported in a semidependent position. No strenuous exercise was taken in the two hours before the measurements. After inflation of the cuff three readings of Korotkoff sounds $\mathrm{I}$ and $\mathrm{V}$ were taken and the means used for analysis. The fifth (instead of the fourth) Korotkoff sound was used because it is more reliably heard. ${ }^{5}$ All measurements were made by the same observer throughout the study. Data were normally distributed and results were expressed as standard deviation scores by reference to age and sex matched 1987 Task Force standards, by using the formula SD score $=($ measurement - mean $) /$ standard deviation, where the mean and standard

TABLE IV - Characteristics of 16 patients with glomerular filtration rate $\leqslant 80 \mathrm{ml} / \mathrm{min} / 1 \cdot 73 \mathrm{~m}^{2}$ surface area at review

\begin{tabular}{|c|c|c|c|c|c|c|c|}
\hline Sex & $\begin{array}{c}\text { Age } \\
\text { (years) }\end{array}$ & $\begin{array}{l}\text { White blood } \\
\text { cell count } \\
\left(\times 10^{4} / 1\right)\end{array}$ & $\begin{array}{l}\text { Duration of } \\
\text { dialysis } \\
\text { (days) }\end{array}$ & $\begin{array}{l}\text { Age at } \\
\text { follow up } \\
\text { (years) }\end{array}$ & $\begin{array}{l}\text { Glomerular } \\
\text { filtration rate }\end{array}$ & $\begin{array}{c}\text { Urinary } \\
\text { albumin to } \\
\text { creatinine ratio } \\
(\mathrm{mg} / \mathrm{mmol})\end{array}$ & $\begin{array}{l}\text { Systolic blood } \\
\text { pressure } \\
\text { (SD score) }\end{array}$ \\
\hline F & 1.5 & $27 \cdot 6$ & 12 & $14 \cdot 6$ & 15 & $114 \cdot 7$ & 1.87 \\
\hline $\mathrm{F}$ & 0.6 & $20 \cdot 0$ & 68 & $14 \cdot 4$ & 37 & 134.5 & 1.24 \\
\hline$M$ & 3.0 & $17 \cdot 2$ & 16 & $8 \cdot 0$ & 52 & $81 \cdot 3$ & 1.98 \\
\hline$M$ & $1 \cdot 3$ & $10 \cdot 1$ & 14 & $8 \cdot 4$ & 55 & 6.9 & 0.79 \\
\hline $\mathrm{F}$ & 2.5 & $21 \cdot 3$ & 17 & $8 \cdot 5$ & 56 & $139 \cdot 8$ & 1.50 \\
\hline$M$ & $1 \cdot 3$ & $22 \cdot 0$ & 24 & 6.5 & 60 & 151.8 & $1 \cdot 18$ \\
\hline$M$ & $2 \cdot 3$ & 29.5 & 17 & $7 \cdot 4$ & 62 & 0.8 & $1 \cdot 40$ \\
\hline $\mathrm{F}$ & $1 \cdot 1$ & $19 \cdot 6$ & 5 & $6 \cdot 6$ & 63 & $0 \cdot 7$ & 1.72 \\
\hline $\mathrm{F}$ & $0 \cdot 3$ & $20 \cdot 3$ & & $16 \cdot 8$ & 65 & $9 \cdot 0$ & 1.06 \\
\hline $\mathrm{F}$ & $1 \cdot 3$ & $25 \cdot 3$ & 11 & $10 \cdot 7$ & 68 & 0.9 & 1.69 \\
\hline $\mathrm{F}$ & 2.5 & 18.0 & 8 & 11.5 & 72 & 0.5 & 1.22 \\
\hline$M$ & 3.0 & 24.9 & 15 & 11.9 & 74 & $0 \cdot 3$ & $0 \cdot 38$ \\
\hline$M$ & 0.6 & $14 \cdot 2$ & 12 & 18.8 & 74 & $0 \cdot 2$ & 1.02 \\
\hline$M$ & $1 \cdot 2$ & 43.5 & 12 & $6 \cdot 1$ & 75 & $9 \cdot 0$ & $1 \cdot 20$ \\
\hline$M$ & $0 \cdot 3$ & 21.0 & & $16 \cdot 2$ & 80 & $0 \cdot 3$ & $0 \cdot 16$ \\
\hline F & $5 \cdot 8$ & 11.4 & 12 & $12 \cdot 6$ & 80 & $7 \cdot 0$ & $0 \cdot 66$ \\
\hline
\end{tabular}

deviation were those of the normal sex and age matched population. ${ }^{6}$

Urine-The early morning urine sample was collected in a plastic bottle containing merthiolate 1:10 000 to prevent bacterial growth. The urine creatinine concentration $(\mathrm{mmol} / \mathrm{l})$ was measured by an autoanalyser Jaffe reaction with an intra-assay coefficient of variation of $3 \%$. Urine albumin concentration $(\mathrm{mg} / \mathrm{l})$ was measured by double antibody radioimmunoassay with a commercially available kit (Diagnostic Products Corporation, Los Angeles, California, USA) with a sensitivity of $0.5 \mathrm{mg} / \mathrm{l}$, an intra-assay coefficient of variation of $4 \%$, and an interassay coefficient of $5 \%$. The ratio of urinary albumin to creatinine concentration was expressed as $\mathrm{mg} / \mathrm{mmol}$ and was $\log$ transformed before statistical analysis; results were expressed as the geometric mean and range (2 SD) calculated on log data.

Glomerular filtration rate was estimated from the plasma clearance of chromium-51 EDTA by single compartmental analysis ${ }^{7}$ and the results expressed in $\mathrm{ml} / \mathrm{min} / 1 \cdot 73 \mathrm{~m}^{2}$ surface area.

Plasma renin activity - One $\mathrm{ml}$ of venous blood was taken from the patients after they had rested supine for two hours. Plasma renin activity was measured with a semimicro radioimmunoassay ${ }^{8}$ and expressed as ng angiotensin I l/hour. Interassay and intra-assay coefficients of variation were $10 \%$ and $5 \%$ respectively.
As for blood pressure, SD scores were calculated for plasma renin activity compared with age matched controls.

Statistical analysis-A one sample $t$ test was used to compare systolic and diastolic blood pressure SD score and plasma renin SD score with the notional value of zero. The geometric means of the urinary albumin to creatinine ratio were compared by an unpaired $t$ test on $\log$ transformed data. The interrelations between glomerular filtration rate, blood pressure, SD score, and urinary albumin to creatinine ratio were examined by linear regression and Pearson's correlation coefficients. The ages and durations of dialysis for the children in two outcome groups (defined according to glomerular filtration rate) were compared with the Mann-Whitney test for comparison of two values, and the geometric means of the total white cell counts in the two groups were compared by using an unpaired $t$ test on $\log$ transformed data.

\section{Results}

The mortality during the acute phase of the disease was 3/35 (9\%) before 1980 and 2/68 (3\%) after 1980 (table I). The overall mortality between 1966 and 1985 was $8 / 103(8 \%)$. Three children went into end stage renal failure without recovering function. Two children had neurological sequelae: one had a left sided hemiparesis and the other had spastic diplegia and cortical blindness.

In the 88 children followed, the mean (SD) systolic blood pressure SD score was $0 \cdot 38(0 \cdot 67)$ significantly greater than zero $(t=5 \cdot 28, \mathrm{p}<0 \cdot 001)$, but no child had a score greater than $2 \cdot 0$ (table III). The mean diastolic score was $0 \cdot 10(0 \cdot 76)$, which was not significantly different from zero $(t=1 \cdot 23, \mathrm{p}=0 \cdot 22)$. The geometric mean ratio of albumin to creatinine in the early morning urine sample was 1.27 (range $0 \cdot 03-48 \cdot 2)$, significantly higher than the value of 0.32 $(0 \cdot 05-1 \cdot 95)(t=5 \cdot 97, \mathrm{p}<0 \cdot 0001)$ in 77 normal children (fig 1). ${ }^{9}$ Of the 88 children with diarrhoea associated haemolytic uraemic syndrome $27(31 \%)$ had a ratio $>2 \mathrm{SD}$ above the normal mean. The mean glomerular filtration rate was $95.1(22.7) \mathrm{ml} / \mathrm{min} / 1.73 \mathrm{~m}^{2}$ surface area (range $15-160 \mathrm{ml} / \mathrm{min} / 1.73 \mathrm{~m}^{2}$ ), and 16 of the patients had a rate $\leqslant 80 \mathrm{ml} / \mathrm{min} / 1.73 \mathrm{~m}^{2}$ (table IV). Nine of these children had both a glomerular filtration

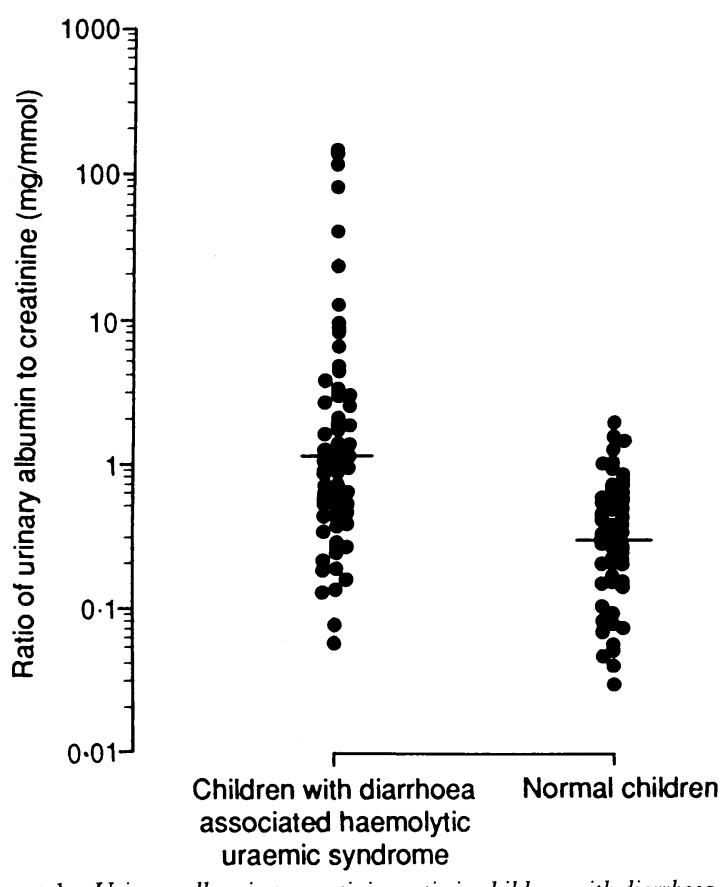

FIG 1-Urinary albumin to creatinine ratio in children with diarrhoea associated haemolytic uraemic syndrome and normal controls 


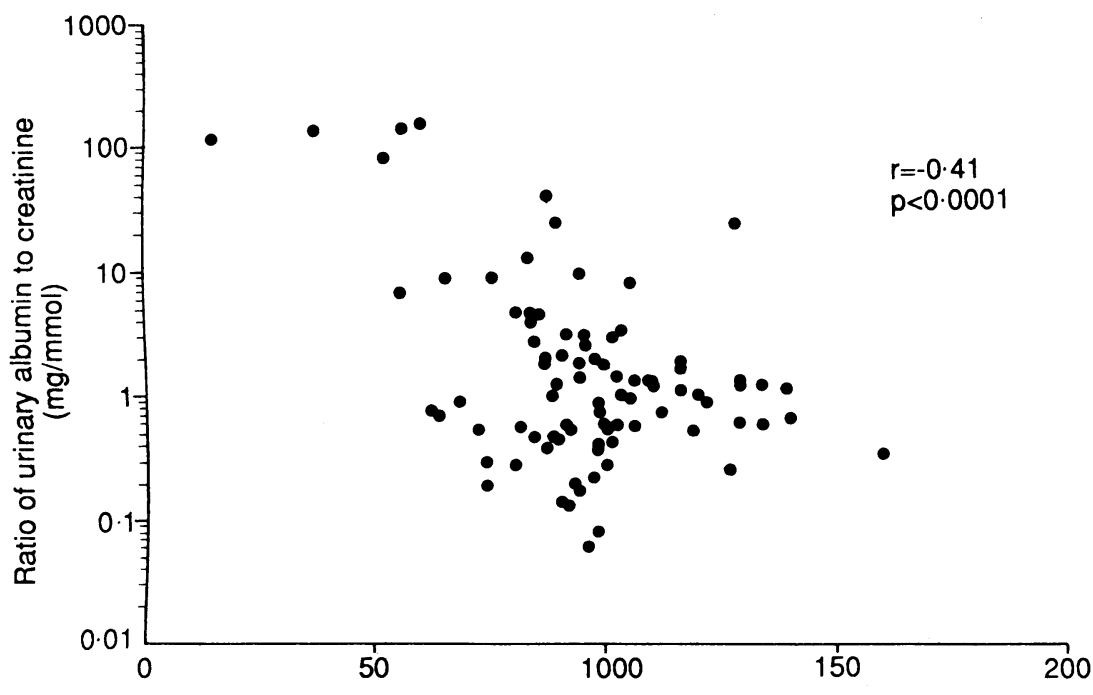

Glomerular filtration rate $\left(\mathrm{ml} / \mathrm{min} / 1 \cdot 73 \mathrm{~m}^{2}\right.$ surface area)

FIG 2-Relation between glomerular filtration rate and urinary albumin to creatinine ratio at follow up in 88 children with diarrhoea associated haemolytic uraemic syndrome

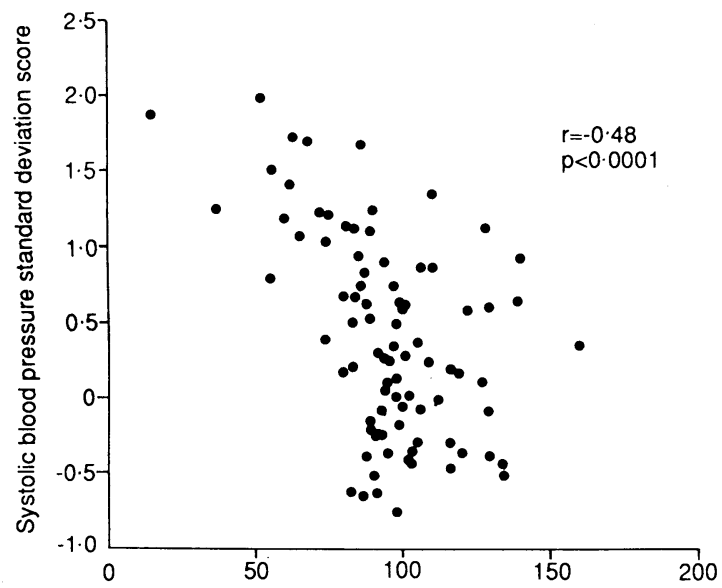

Glomerular filtration rate $\left(\mathrm{ml} / \mathrm{min} / 1.73 \mathrm{~m}^{2}\right.$ surface area)

FIG 3-Relation between glomerular filtration rate and systolic blood pressure $S D$ score at follow up in 88 children with diarrhoea associated haemolytic uraemic syndrome

rate $<80 \mathrm{ml} / \mathrm{min} / 1.73 \mathrm{~m}^{2}$ and a urinary albumin to creatinine ratio $>2$ SD above the normal mean. Data on plasma renin activity were available in only 41 children. The mean (SD) plasma renin SD score was $0.60(0.97)$, which was significantly greater than zero $(t=3 \cdot 9, \mathrm{p}<0 \cdot 001)$. We found significant negative correlations between glomerular filtration rate and urinary albumin to creatinine ratio $(r=-0.41$, $\mathrm{p}<0.0001$ ) and glomerular filtration rate and systolic blood pressure SD score $(r=-0 \cdot 48, p<0 \cdot 0001)$ (figs 2 and 3 ) and a significant positive correlation between urinary albumin to creatinine ratio and systolic blood pressure SD score $(r=0.25, p=0.02)$ (fig 4). No correlation was found between plasma renin SD score and any of the other variables measured.

The patients were divided into two groups: group 1 included 16 who at follow up had a glomerular filtration rate $\leqslant 80 \mathrm{ml} / \mathrm{min} / 1 \cdot 73 \mathrm{~m}^{2}$ surface area, which is considered to be the lower limit of normal, and three who had died after end stage renal failure; group 2 consisted of 72 patients with a glomerular filtration rate $>80 \mathrm{ml} / \mathrm{min} / 1.73 \mathrm{~m}^{2}$ at the time of reinvestigation. We found no significant difference in the age at presentation: in group 1 the mean age was $2 \cdot 1$ $(0 \cdot 25-11 \cdot 0)$ years compared with $3 \cdot 5(0 \cdot 4-14 \cdot 0)$ years in group $2(\mathrm{z}=0 \cdot 86, \mathrm{p}=0 \cdot 38)$. Children in group 1 had a significantly higher total white blood cell count at presentation (geometric mean 20.9 (range 10.5-41.6) $\times$ $\left.10^{9} / 1\right)$ than those in group $2\left(15 \cdot 1(5 \cdot 0-45 \cdot 7) \times 10^{9} / 1\right.$; $t=-2 \cdot 4, \mathrm{p}=0 \cdot 01)$. The duration of dialysis was also significantly longer in group $1(21 \cdot 1(17)$ days) than in group $2(9.1(6.0)$ days; $z=2.91, p<0.001)$; this analysis excludes the 22 children $(24 \%)$ who were not receiving dialysis at the time of presentation. Eight $(57 \%)$ of the 14 patients who received dialysis for 16 days or more had a reduced glomerular filtration rate, whereas only $11(14 \%)$ of the 74 receiving dialysis for less than 16 days had a glomerular filtration rate $<80 \mathrm{ml} / \mathrm{min} / 1.73 \mathrm{~m}^{2}$ at follow up (table $\mathrm{V}$ ).

\section{Discussion}

Diarrhoea associated haemolytic uraemic syndrome is one of the major causes of acute renal failure in childhood. The immediate prognosis has improved substantially over the past two decades as short term dialysis has become a widely available and safe form of treatment. Most recent series report an acute fatality rate of $5-10 \%{ }^{10-13}$; in our study the mortality during the acute phase was $5 \cdot 0 \%$. The long term consequences of haemolytic uraemic syndrome are, however, less well documented, with various outcomes being reported from different centres and regions. ${ }^{1011} 11+10$ The aim of this study was to assess renal function in a large group of children with a minimum follow up of five years, after an acute episode and to provide more reliable data on the long term prognosis of the condition.

In this series 3/103 (3\%) of patients did not recover renal function after presentation and 34/88 $(39 \%)$ had some abnormality of renal function at the time of follow up. Eighteen per cent had a glomerular filtration rate $<80 \mathrm{ml} / \mathrm{min} / 1.73 \mathrm{~m}^{2}$ and $31 \%$ had significant microalbuminuria. Three per cent of patients became hypertensive after their acute illness and were taking antihypertensive drugs at follow up. The remainder had systolic blood pressure SD score $<2$, but the mean systolic blood pressure SD score for the group as a whole was significantly greater than zero. The mean plasma renin activity SD score was also greater than zero. We found that a lower glomerular filtration rate, microalbuminuria, and a higher systolic blood pressure were associated.

We divided our survivors into two groups on the basis of glomerular filtration rate: $<80$ (group 1) and $>80 \mathrm{ml} / \mathrm{min} / 1.73 \mathrm{~m}^{2}$ (group 2). There was no difference in the age at presentation between the two groups, but patients in group 1 had a significantly higher white blood count at presentation and a significantly longer duration of dialysis. Recent publications analysing prognostic features in haemolytic uraemic syndrome have produced variable results with regard to the significance of age at presentation, the duration of anuria or dialysis, and the presence of central nervous system involvement, ${ }^{117-19}$ but polymorphoneutrophil leucocytosis is consistently related to poor outcome. ${ }^{1 x-21}$

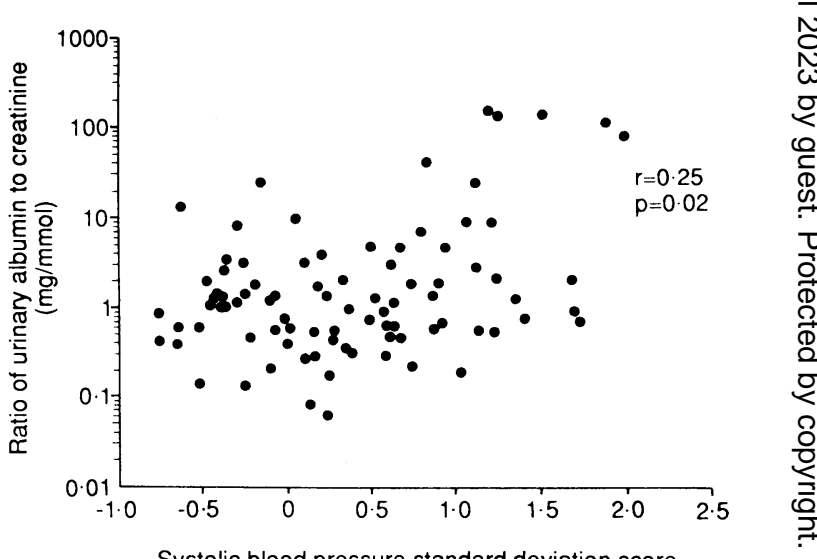

FIG 4 - Relation between systolic blood pressurd deviation score albumin to creatinine ratio at follow up in 88 children with diarrhoed associated haemolytic uraemic syndrome 
Follow up studies published over the past years have produced conflicting results with regard to renal outcome after an episode of haemolytic uraemic syndrome. The largest series, published before the widespread availability of acute dialysis, is from Argentina, where haemolytic uraemic syndrome is common." Of 124 survivors followed for a minimum of five years, only 60 $(48 \%)$ made a full recovery; $23(18 \%)$ progressed to end stage renal failure. More recent data have pointed to a better outcome. Van Dyck et al added their findings to those from studies in Utrecht, London, and Paris, and in a total of 258 patients from western Europe found an acute mortality of $9 \%$, progression to end stage renal failure in $9 \%$, chronic renal failure in $4 \%$, late sequelae in $12 \%$, and complete recovery in $66 \% .^{13}$ The data from these different centres are, however, difficult to interpret. In these series no clear distinction has been made between haemolytic uraemic syndrome with and without the diarrhoeal prodrome and it is now known that most children with no antecedent diarrhoea have a poor prognosis. ${ }^{2: 2}$ Different methods of assessing renal function were used in the different centres and the duration of follow up was inadequate in some instances. In comparison with Van Dyck et al's results we found a lower acute mortality $(5 \%)$ and fewer children progressing to end stage renal failure (3\%) but a higher proportion of children with renal sequelae (39\%). In a recent publication from the Argentinian group, Perelstein et al found that children with a history of haemolytic uraemic syndrome and normal renal function, as determined by standard diagnostic procedures, had a loss of normal renal functional reserve after a protein load when compared with normal controls. ${ }^{24}$ This suggests that the extent of residual renal problems following diarrhoea associated haemolytic uraemic syndrome may have been underestimated.

Most of our patients had been discharged from hospital follow up and were not under regular medical review. In view of the substantial number of patients with renal sequelae we suggest that children who have had an episode of diarrhoea associated haemolytic uraemic syndrome be kept under medical review with blood pressure measurement and urine testing. Because of the positive correlation between microalbuminuria and systolic blood pressure and the negative correlation of microalbuminuria and glomerular filtration rate, patients with noticeable microalbuminuria on routine testing should be more closely monitored, with measurement of glomerular filtration rate. Milford et al have suggested measurement of the ratio of protein to creatinine in an early morning sample of urine as an effective means of monitoring the progress of patients after an episode of diarrhoea associated haemolytic uraemic syndrome..$^{25}$ They examined the prognostic value of changes in these ratios in 40 children one year after diagnosis and found that $87 \%$ of those who seemed to have fully recovered had normal ratios, compared with none of those with poor outcomes."

Diarrhoea associated haemolytic uraemic syndrome is now emerging as an important clinical and public health problem, and there is evidence that its incidence is increasing, particularly in young children..$^{20210}$ This study shows it is associated with substantial morbidity, and a considerable number of patients have evidence of occult nephropathy at follow up. The abnormalities in many patients are subtle and the long term implications unclear; some may show further decline in renal function or become hypertensive. This disease may consequently have an increasing impact in adult nephrology.

1 Gasser C, Gautier E, Steck A, Sicbenmann RE, Oeschslin R. Hämolytischurämische Syndrome: Bilaterale Nierenrindennekrosen bei akuten erworbenen haemolytischen Aanamien. Schweiz Med Wochenschr 1955;85: $905-9$

2 Levin M, Barratt TM. Haemolytic uraemic syndrome. Arch Dis Child 1984;59:397-400.

3 Karmali MA, Steele BT, Petric M, Lim C. Sporadic cases of haemolytic uratemic syndrome associated with faecal cytotoxin and cytotoxin-producing Escherichia coli in stools. Lancet 1983;i:619.

+ Wright BM, Dore CF. A random zero sphygmomanometer. Lancet 1970;i:337. 5 L.onde S. Fifth versus fourth Korotkoff phase. Pediatrics 1985;76:460-1.

6 National Heart, Lung, and Blood Institute, Bethesda, Maryland. Report of the Second Task Force on Blood Pressure Control in Children, 1987: Pediatric 1987;79:1-25

7 Chantler C, Barratt TM. Estimation of glomerular filtration rate from plasma clearance of 51-chromium edetic acid. Arch Dis Child 1971;47:613.

8 Dillon MJ, Ryness J. Measurement of plasma renin activity by semi-micro radioimmunoassay of generated angiotensin 1. f Clin Pathol 1975;28: $625-30$

9 Gibb DM. Early markers of the renal complications of insulin-dependent diabetes mellitus in children [dissertation]. Bristol: University of Bristol, 1990.

10 Gianantonio $\mathrm{CA}$, Vitacco $M$, Mendilaharzu F, Gallo GF, Sojo ET. The hemolvtic uremic syndrome. Nephron 1973;11:174-92.

11 Trompeter RS, Schwartz R, Chantler C, Dillon MJ, Haycock GB, Kay R, et al. Haemolytic-uraemic syndrome: an analysis of prognostic features. Arch Dis Child 1983:58:101-5

12 Kaplan BS, Katz J, Krawitz S, Lurie A. An analysis of the results of therapy in 67 cases of the hemolytic-uremic syndrome. I Pediatr 1971;78:420-5.

13 Van Dick M, Proesmans W, Depraetere M. Hemolytic uremic syndrome in childheod: renal function ten vears later. Clin. Nephrol 1988;29:109-12.

14 Donckerwolke RA, Kuyten RH, Tiddens HA, Van ( $r(x) l$ J1). Haemolyti uraemic sindrome. Puediatrician 1979;8:378-93.

15 Bindi ki Muaka P, Proesmans W, Eeckels R. The haemolytic-uraemic syndrome in childhood: a study of the long term prognosis. Eur f Pediat 1981;136:237-43.

16 Habib R, Levy M, Gagnadoux MF, Brover M. Prognosis of the hemolytic uremic syndrome in children. Adv Nephrol 1982;14:109-28.

17 Loirat C, Sonsino E, Varga Moreno A, Pillion G, Mercier JC, Beaufils F, et al. Haemolytic-uremic syndrome: an analysis of the natural history and
prognostic features. Acta Paediatr Scand 1984:73:505-14.

18 Walters MDS, Matthei IU, Kay R, Dillon MJ, Barratt TM. The polymorphonuclear leucocyte count in childhood hemolytic uremic syndrome. Pediatr Nephrol 1989;3:130-4.

19 Sieniawska M, Korniszewska J, Gura C, Welc-Dohies J, Lewicki Z. Prognostic significance of certain features in the hemolytic-uremic synPrognostic significance of certain fear

20 Martin DL, MacDonald KL, White KE, Soler JT, Osterholm MT. The epidemiology and clinical aspects of the hemolytic uremic syndrome in Minnesota. N Engl f. Med 1990;323:1161-7.

21 Coad NAG, Marshall T, Rowe B, Taylor CM. Changes in the postenteropathic form of the hemolytic uremic syndrome in children. Clin Nephrol 1991;35: $10-6$.

22 Levin $M$, Walters MD, Barratt TM. Hemolytic uremic syndrome. Adv Pediatr Infect Dis 1989;4:51-82.

23 Kaplan BS. Hemolytic uremic syndrome with recurrent episodes: an important subset. Clin Nephrol 1977;8:495-8.

24 Perelstein EM, Grunfeld BG, Simsolo RB, Gimenez MI, Gianantonio CA. Renal functional reserve compared in haemolvtic uraemic syndrome and single kidnev. Arch Dis Child 1991;65:728-31.

25 Milford DV, White RHR, Taylor CM. Prognostic significance of proteinuria one year after onset of diarrhea-associated hemolytic-uremic syndrome. f Pediatr 1991;118:191-4.

26 Milford DV, Taylor CM, Gutteridge B, Hall SM, Rowe B, Kleanthous $\mathrm{H}$ Haemolytic uraemic syndromes in the British Isles 1985-8: association with Haemolytic uraemic syndromes in the Brittsh Isles 1985-8: association with
verecytotoxin producing Escherichia coli. Part 1: clinical and epidemioverecytotoxin producing Escherichia coli. Part

(Accepted 2 fuly 1991)
A Handbook to London has been presented to all the members of the Congress. The English and French versions appear side by side on the same page. The information supplied appears to be of a thoroughly reliable and practical character, and the maps must have been of great assistance to persons unfamiliar with London; in addition to the ordinary guidebook maps, there are others showing the situations of the hospitals of London, of the cemeteries and prisonsa lugubrious collocation-and, out of compliment to the demographers, a chart is added showing the gross present population of the metropolitan parishes and the number of persons per acre.

(British Medical fournal 1891;ii:391) 